\title{
ВНУТРІШНІЙ СВІТ ЯК СИСТЕМА 3 ВИСОКИМ СТУПЕНЕМ НЕЛІНІЙНОСТІ
}

\section{Папуча Микола Васильович}

Доктор психологічних наук, професор, завідувач кафедри загальної та практичної психології, Ніжинський державний університет імені Миколи Гоголя, м. Ніжин (Україна)

\begin{abstract}
Анотація. У статті аналізується істотна відмінність системи «внутрішній світ» від інших систем високої складності і нелінійності, яка полягає в ї̈ керованості (не лише собою, своєю динамікою - самоорганізачія), а й зовнішнім по відношенню до системи фактором людиною, яка июю систему має. Доводиться, щуо особистість, і тільки вона, виступає суб'єктом власного внутрішнього світу. Відмічається, щзо внутрішній світ має такі обов 'язкові параметри, як великий рівень складності, висока нелінійність, упорядкованість $i$ структурованість (a отже - ієрархізованість), сингулярність, здатність до продуктивності, розвитку $i$ саморозвитку. Підкреслюється, щуо здійснення управлінсько-регулятивних (власне, суб'єктних) функиій по відношенню до внутрішнього світу відбувається через його структурування $i$ переструктурування, у тому числі і основним чином в процесі цілком зовнішньої діяльності.
\end{abstract}

Ключові слова: внутрішній світ, особистість, система, розвиток.

Постановка проблеми. Вже сам термін „світ” передбачає, що система, про яку йдеться, має такі обов'язкові параметри, як великий рівень складності, висока нелінійність, упорядкованість і структурованість (а отже - ієрархізованість), сингулярність, здатність до продуктивності, розвитку і саморозвитку. Істотна відмінність системи «внутрішній світ» від інших систем високої складності і нелінійності полягає в їі керованості (не лише собою, своєю динамікою - са- моорганізація), а й зовнішнім по відношенню до системи фактором - людиною, яка цю систему має. Особистість, і тільки вона, виступає суб'єктом власного внутрішнього світу. Коли ми говоримо тут «особистість», маємо на увазі людину як єдність (свідоме і несвідоме, тілесне і духовне, систему Я, а також те, що складає iї «зовнішній життєвий світ»). Щоправда, це управління власним внутрішнім світом відбувається не завжди з однаковою ефективністю, а іноді, на відносно короткий проміжок 
часу, взагалі припиняється, що, між іншим, є серйозним підтвердженням цілісної структурованості і відносної самостійності внутрішнього світу. Такі явища ми спостерігаємо в період вікових і життєвих криз, психотравм, важких соматичних розладів, феєричного захоплення людини якимось почуттям («пікові переживання» за Маслоу, або, з іншого боку, афективні стани), при психічних захворюваннях. Ми хотіли б уточними позицію - мова не йде про людину як суб'єкта власної поведінки. Наша гіпотеза полягає в тому, що людина є суб'єкт власного внутрішнього світу, який продукує ту чи іншу поведінку. Здійснення управлінсько-регулятивних (власне, суб'єктних) функцій по відношенню до внутрішнього світу відбувається через його структурування i переструктурування, у тому числі і основним чином в процесі цілком зовнішньої діяльності. Отже, центральним тут $є$ поняття «структура». Це поняття є, мабуть, таким же старим, як сама психологія, то ж ми не будемо пускатися в історичні екскурси, а проаналізуємо відносно нові, на наш погляд, дуже цікаві уявлення про структуру.

Свого часу визначення структури дав Л. С. Виготський: «Структурою прийнято називати такі цілісні утворення, які не складаються сумарно із окремих частин, являючи собою ніби їх агрегат, але самі визначають долю і значення кожної частини, що входить до їх складу» [4, с. 256]. Отже, структура має щось ще, крім частин, що їі складають, і саме це загадкове «ще» дає можливість їй визначати власне існування i, в тому числі, комбінації своїх складових частин. Розв'язати це питання - означає відповісти на дуже багато питань психології, в цілому. Ми не ставимо перед собою таку глобальну задачу, але ясно одне - ця відповідь лежить в площині розвитку, генезису. Якщо б вдалося вивчити генезу структури (будь-якої психологічної структури взагалі), тобто - १ї виникнення, розвиток, існування, руйнацію (перехід в іншу структуру), це б дало відповідь на поставлене питання - що ж робить структуру структурою (так як іiі розуміє Виготський).

\section{Аналіз останніх досліджень та публі-} кацій.

Зараз психологічні структури активно вивчаються в межах структурнометодологічної парадигми, яку в російській психології активно і плідно розробляє М. О. Холодна [20]. При цьому, головна мотивуюча теза, з якою ми абсолютно погоджуємося, полягає в наступному: «...природу будьякого явища не можна зрозуміти на рівні опису його властивостей. Пояснити природу тієї чи іншої реальності означає відкрити іiі структуру, адже структура є основою іiї функціонування» [20, с. 78]. До речі, цю думку вперше в вітчизняній психології висловив Л. М. Веккер [20, с. 79]. Ми, повторимо, повною мірою розділяємо наведену думку, але, залишаючись на позиціях генетичних, вимушені тут вступити в діалог 3 нею («діалог ідей», - Бейтсон [1]). Ві- 
домо, що свого часу О. М. Леонтьєв переконливо довів, що функція передує структурі і породжує іiі [8]. Нам уявляється, що діалогічне поєднання цих двох протилежних, по суті, позицій, буде означати створення центральної методологеми дослідження процесу структурування внутрішнього світу. 3 одного боку, як і всі інші структури (органи) людини, внутрішній світ перетворюється на структуровану цілісність в процесі функціонування живої істоти. I тут дійсно права Л. І. Анциферова людина є суб'єктом власного внутрішнього світу. 3 іншого боку, складно структурований внутрішній світ дійсно багато в чому визначає функціонування і розвиток людини як цілого. Але $є$ ще цікавий момент - в процесі цього функціонування, внутрішній світ не залишається незмінним - він весь час переструктуровується, до-будовується і т. д. I тут виникає інша ділема - а що у внутрішньому світі є сталим - тим, що визначає життєвий шлях і робить людину індивідуально-неповторною i стабільно самототожною. ...Так, чи інакше, ми повинні мати мужність визнати, що наш власний внутрішній світ нам не дано пізнати $і$ зрозуміти до кінця, як і світ зовнішній. Справедливо буде відзначити, що ще Л. М. Лопатін писав: «...в нашому внутрішньому світі, хоча він повною мірою відкритий нашій самосвідомості, далеко не все ясно для нас самих і далеко не все вміщується у чіткі і визначені формули» [9, с. 230]. Як бачимо, з тих часів змінилось не так вже й багато, принаймні в цьому питанні. I в першу чергу це стосується механізмів і особливостей взаємодії свідомого й несвідомого (за грубою аналогією - «цей» і «той» світ). Ми можемо зараз сказати, що внутрішній світ людини це $є$ (за винятком Яструктури) вся іï складно і багатомірнорухливо структурована психіка (Ч). Ми, далі, можемо сказати погоджуючись із К. К. Платоновим (у нього, нагадаємо, йшлося щоправда про структуру особистості [11]), внутрішній світ - складно-складно структурована психіка, оскільки вся структура як ціле є неоднорідною і складається, в свою чергу із складних і неоднорідних структур нижчого порядку (К. К. Платонов назвав їх «підструктурами»). Ми можемо додати із галузі синергетики, що внутрішній світ $\epsilon$ система, що самоорганізується, що вона має високий ступінь нелінійності, а від цього - відноситься до, так званих, пульсуючих структур [5]. I що принцип іiї влаштування є фрактал, тобто гармонія негармонійного різноманіття (коли воно об'єднується в цілісність), яка ніколи не завершується.

Незавершеність структури (а, відповідно, і структурування) внутрішнього світу слід розуміти не як недолік (недовершеність, недоробленість), а як його готовність, відкритість завжди через систему активності, зокрема, переживань, розвиватися і змінюватися.

Постановка завдання. На основі викладеного можна сформулювати завдання дослідження, яке полягає в аналізі психологічних особливостей внутрішнього світу особис- 
тості як системи 3 високим ступенем нелінійності, що самоорганізуеться.

Виклад основного матеріалу дослідження. Що ж являє собою внутрішній світ людини? Як його можна уявити? Нам уявляється, що природа його подвійна і найлегше це порівняти з електроном. Внутрішній світ одночасно структура i процес (структурований процес або процесуальна структура). Він упорядкований, має стабільні складові і «точки відліку» - структурні показники; і разом з тим, він - постійний плин (процес), в ході якого виникають, існують, виконуючи певні функції, руйнуються нові структури, частина яких стає стабільними. Те, що не охоплене структуруванням - чуже для цього світу, травмує, бентежить, і відбувається або робота переживання по «введенню» цього «чужого» в структуру (перетворення його на структуру), або робота «фрейдівських» механізмів захисту, що полегшує, але, при цьому, ускладнює проблему.

Отже, структура внутрішнього світу людини розуміється нами, ніби 3 двох позицій. По-перше, структура як упорядкована цілісна єдність всього внутрішнього світу. При цьому, ми солідаризуємось з М. О. Холодною, яка зауважує, що не треба розуміти все доволі примітивно, і ціле бачити «великим», яке вміщує в собі, охоплює всі частини. Ціле, відносно структури психіки, може, навпаки бути «маленьким», максимально згорнутим, сингулярним [20, с. 79$]$ і розгортатися певними сво- їми складовими в окремих процесах і подіях внутрішнього світу (зазначимо, що ця точка зору не просто приваблива, вона тяжіє до Сxiдної філософії, яка, як засвідчує життя, краще розбирається у внутрішньому світі людини; жаль тільки, що ми ії поки не знаємо).

Друга позиція - структури «нижчого порядку», з яких складається вся структура $\mathrm{i}$ дія яких, утворення і руйнація, а головне, зв 'язки між ними і визначають психічну активність. Про це яскраво сказав С. Л. Рубінштейн: «Аналіз ролі внутрішнього призводить до розуміння існування різного роду зв'язків. Основа, яка породжує інші зв'язки, причина цих зв'язків - структура, тобто структурні зв'язки, - об'єднують окремі елементи, аспекти або сторони в єдине ціле. Багато і при цьому, важливих, законів виражають саме структуру зв'язку. Саме структура зв'язку, яка об'єднує різні сторони в одне єдине ціле, і $є$ тим внутрішнім зв'язком, який утворює єдине ціле, що опосередковує сумарний ефект зовнішньої причини» [13, с. 372]. Отже, С. Л. Рубінштейн бачив, що зв'язок між структурами теж має свою структуру! Це - відкриття, але, на жаль, в межах даної роботи, ми не можемо присвятити йому повноцінної уваги.

Ми тепер можемо дати визначення психологічній структурі, яке, на наш погляд, на даний час, найбільш адекватно відображає іiі природу. (Це визначення запозичуємо з синергетики). «Структура - це локалізований в певних частинах середовища процес. Інакше ка- 
жучи - це процес, який має певну форму, здатний, до того ж перебудовуватися (переструктуровуватися) i переміщатися в цьому середовищі. Отже, структура є процес або п'ятно процесу, що мігрує в середовищі» [7, с. 6]. Є фантастично-захоплююча загадка в тому, що психологічна структура у внутрішньому світі може за певних умов перетворитися на процес (групу процесів, увійти в інші процеси), а потім якимось дивним чином, «не забуваючи про свої складові», в ще нових умовах знову стати тією ж (або трішечки іншою) структурою.

I ще одне. Якщо в психіці діють закони синергетики (а це майже гарантовано, адже психіка людини за усіма параметрами підходить під розуміння складної гетерогенної системи з високою нелінійністю, що самоорганізується), перед нами відкривається зовсім неочікувана захоплююча картина внутрішнього світу людини: в упорядкованому структурованому ієрархізованому просторі нескінченно «мігрують» структури як локалізовані в певному часі і просторі процеси. В процесі їх руху вони утворюють тимчасові структурні зв'язки 3 різними складовими психіки та між собою, розриваючи раніш встановлені зв'язки. Отже вираз «постійний плин» став наповнюватись певним змістом. Цей рух, це життя системи визначає появу різних думок, емоцій, відчуттів, цілей і задумів... Він утворює поведінку, він іноді робить эї незрозумілою (бо логіка - своя, прихована), він же робить людину нескінченно глибокою і різнобарвною і ніколи до кінця незбагненною. Отримують зворотній зв'язок і переживання. Ми весь час проводили думку про те, що переживання - механізм створення структур. Але, виявляється структури, потім, живуть власним життям, і от це життя породжує нові переживання (міграція інтелектуальної структури від виконавських центрів до цілепокладання породжує переживання творчості і це переживання «запускає» механізм створення чогось нового, звичайно, опосередковано, через створення нової структури). Можуть закинути, що описані процеси можуть бути геть неупорядкованими, і це правда - вони тяжіють до неупорядкованості. А в реальності, найчастіше ми спостерігаємо все ж упорядковане існування людини. Ми відповімо, що існує, як би два різні «захисти» упорядкованості. Перший з них належить самій системі і від людини як суб'єкта не залежить. Головне ж в житті людини - «захист» пов’язаний 3 особистістю і ії життєвим шляхом. 3 цього і почнемо.

Але спочатку - про психологічну природу того, що ми називаємо структурою. Ми не можемо зараз обговорювати надскладне (непідйомне) для сучасної психології питання загальної структури внутрішнього світу як цілісності. Але ця цілісна структура (або структурована цілісність), не складається з окремих уламків, процесів, станів, властивостей. Вона - саме структурована, отже складається 3 різних за природою упорядкованих і поєдна- 
них між собою структур (підструктур). Ми не можемо сказати, що існує інструментарій, який міг би слугувати методом (і системою методичних прийомів), за допомогою яких ми можемо емпірично вивчати психологічну природу цих структур 2-го порядку (власне, підструктур, які ми будемо називати для зручності - структурами). Але ми маємо величезну кількість даних, отриманих опосередковано і безпосередньо, в діяльності зовнішній і внутрішній, сукупність яких дає нам можливість попередньо висловитись щодо психології даних утворень. Безумовним $\epsilon$ те, що вони дуже різні і складні, але влаштовані при цьому за єдиним принципом - це принцип міжфункціональних психічних систем (Л. С. Виготський [3], О. М. Леонтьєв [8]), або тимчасових психологічних органів (О. О. Ухтомський [18]). Будьяка структура містить в собі когнітивний, емоційний, мотиваційний та життєво-смисловий компоненти. Причому, тільки 3 вибудовою останнього вона перетворюється на дійсну структуру, відносно самостійну i, в той же час, пов'язаною сполучально з іншими структурами. Структури рухливі i тимчасові (дійсно, локалізовані в часі і просторі процеси), але ця тимчасовість може бути дуже різною за часовим показником. Структури виникають або повільно і поступово, або миттєво (інтуїція - миттєве виникнення структури), змінюють внутрішній світ, «мігруючи» ним, потім зникають, але досвід Я зберігає пам'ять і може відтворити в будь-який момент будь- яку структуру. Це не є структури свідомості, а структури всього внутрішнього світу, тому вони містять значний аспект неусвідомлюваного і тому, зокрема, так важко піддаються дослідженню.

Складність будови структур, складність їх існування дозволяе припустити, що структурування внутрішнього світу особистості, це далеко не лише синонім терміну упорядкування. Це - і урізнобарвлення, це розвиток, ускладнення і динамізм дуже складного цілого, причому, такого цілого, яке має виражений індивідуальний характер. 3 цього приводу гарно висловився К.-Г.Юнг: «У всій людській діяльності є апріорний фактор, так звана вроджена, досвідома і безсвідома структура душі... і в той момент, коли перші прояви психічного життя стають доступними спостереженню, треба бути сліпцем, щоб не визнати їх індивідуальний характер, тобто неповторну особистість, що стоїть за ними» [23, с. 214].

В той же час, ми вважаємо, що «вроджена» структура душі (структура внутрішнього світу) не дана, а задана як можливість. Лише процес онтогенезу, що протікає в соціальному (і біологічному, тілесному - безумовно!) оточенні, робить цю «заданість» реальнісТю.

В цілому, ми приєднуємось (в такій формі) до думки К.-Г. Юнга і ряду сучасних дослідників, які вважають, що внутрішній світ особистості є відпочатково неструктурованим [14; 19; 24]. Звідси, і особливості поведінки. 
На наш погляд, наступні фактори, що складають саме життя «запускають» механізм переживання і отже структурування (деякого упорядкування, розвитку і ускладнення) внутрішнього світу людини:

- онтогенетичний розвиток;

- взаємодія з оточенням;

- постановка і досягнення власних цілей і мотивів переживання власних психічних станів, емоцій, вражень;

- переживання життєвих подій, в тому числі, екстремальних;

- внутрішні процеси самої системи «особистість», як системи складної, гетерогенної, такої, що саморозвивається і самоорганізується і має високий ступінь складності і нелінійності.

В постнекласичній парадигмі, яка все більше розповсюджується в психології, внутрішній світ (психологічні системи - за Л. С. Виготським), якщо включити інстанцію Я, розглядається як складна гетерогенна система $з$ високою нелінійністю, яка саморозвивається і самоорганізується. Організації (структурі, упорядкуванню) тут протистоїть хаос, який розглядається не як фактор негативний, а як дестабілізуючий, що «розхитує» стару структуру i, кінець кінцем породжує 3 себе - нову. Так система розвивається.

Така еволюціонуюча система - «це фрактал, сітка, в якій завжди зберігається певна спадкова структура (невос). Це є чиста структура, без елементів» [2, с. 153]. В синер- гетиці доведено, що фрактальне буття «пізнається через діалог, через полілог» [2, с. 153]. Отже, комунікація є обов'язковою для пізнання еволюціонуючи систем. «Сітка із суб'єктів, що пізнають, пізнає теж сітку - фрактал. У кожного суб'єкта виникають власні моделі реальності, як систем, що змінюються, але тільки сітка моделей несе найбільш повне знання» [2, с. 153]. Причому це знання (принаймні, відносно внутрішнього світу) не проста сума моделей, оскільки модулі виявляються несумісними одна 3 одною. Просто, в різних ситуаціях активізуються різні моделі і їхні сукупності. Можуть виникнути найрізноманітніші сполучання, до яких не додумається жоден з суб'єктів сам по собі. Це сітьове знання [17] (ключова ознака постнекласичної парадигми) і істотну роль в ньому відіграє особистісне (див. у Челпанова) знання. Нам здається, що завдяки означеному принципу, отримані принципово нові, часто неочікувані знання у психології, зокрема, 3 питання структурування внутрішнього світу. I те, що психологія не враховує їх, не використовує - $\epsilon$ хибний шлях. Тут потрібні теоретико-методологічні роботи, які б проклали місток між психологією і найновішими тенденціями науки (зокрема, синергетики). Криза сучасної психології, на наш погляд, полягає у відсутності серйозних спроб в цьому напрямі, i, взагалі адекватного ставлення до серйозних речей. Безумовно, це не буде просто. Адже чому ми вилучили інстанцію Я? Тому, що без 
неї психіка людини, внутрішній світ ідеально підходить під визначення систем, що існують і розвиваються за законами синергетики. 3 цією інстанцією дана ідеальність порушується. Але ж це ніяк не означає, що в системі перестали діяти закони синергетики, це означає, що Я встановлює з ними якісь зв'язки, що і треба посилено вивчати. Тут ми зупинимось лише на можливій на даний момент інтерпретації законів еволюціонуючої системи в галузь психології. При цьому, будемо намагатися обійтися без «чужих» для психології термінів, подаючи їх в дужках лише для тих читачів, хто зацікавиться проблемами синергетики. За нашими даними такою роботою доволі плідно і своєрідно займається в Україні одна людина, О. А. Донченко [6]. Ми знайомі з їі роботами і вдячні автору, але аналізувати їх не будемо, оскільки нам важливо лише показати певний аспект подальшого руху, та i, якщо чесно, ще не прийшов час - це робота дещо на випередження (цінність їх від цього зростає, безумовно). Отже, внутрішній світ людини являє собою складну відкриту гетерогенну систему, 3 високою нелінійністю, яка саморозвивається і самоорганізується (тобто, робить це - сама). Складність системи, за I. Пригожиним [12], визначається кількістю елементів в одиниці простору. У внутрішньому світі вона дуже висока. Гетерогенність означає, що структурні одиниці системи (підструктури) є різними, неоднорідними. Звідси, висока нелінійність тобто великий відсоток зв'язків, що не підпо- рядковані формальній логіці [12]. Одиницею цієї системи (ми визначили ії як підструктуру) $\epsilon$ утворення складне, незавершене, його не можна обрахувати в формально-логічних схемах, і воно являє собою гармонійність утворену із негармонійного. У синергетиці це утворення називається - фрактал.

Розвиток системи, тобто іiї самоорганізація і створення структур невідпорно вимагає стану нестійкості системи. Це досягається наявністю і одночасною діяльністю в системі двох сил, однакових по енергетичному показнику і спрямованих протилежно. Одна 3 них сприяє створенню структур, але, водночас вона нарощує неоднорідності в середовищі (згадаємо гетерогенну природу структури). Само собою, цей процес сприяє появі протилежностей і ніби породжує другу силу, спрямовану на розсіювання структур і розмивання всіх неоднорідностей системи. В режимі дії цієї сили структури не можуть виникати. Але процес розвитку не припиняється. Ця сила породжує хаос, і він, на мікрорівні виступає не фактором руйнації, а силою, що виводить на самоструктурування появою нелінійного середовища (аттрактор). Помічено, що в системах, близьких за природою до людської психіки, діє так званий «дивний аттрактор»- майбутній стан системи. Отже, дана теорія не «відміняє» детермінізм - існування і розвиток внутрішнього світу людини детермінує його майбутнє. Загадка полягає в тому, що в стані нестійкості, хаосу, система знає своє майбутнє 
i iз всих можливих розгалужень напрямів саморозвитку сама обирає один, який є іiі майбуTHE.

Описане, на наш погляд, нагадує відомі в психології речі. По-перше, це розвиток під час вікової кризи: якщо уважно почитати Виготського, можна легко уявити, що він знав (!?) теорію систем, що самоорганізуються, і там ми все знайдемо і про хаос, і про розвиток на мікрорівні, і про майбутнє. По-друге, дві, протилежно спрямовані сили, що визначають розвиток постулював А. Маслоу [10]: одна 3 них, спрямована на стабілізацію, адаптацію системи, інша - на іï дестабілізацію, дезадаптацію і отже, в якомусь сенсі, руйнацію існуючого.

Таким чином, слід згодитись 3 психологічної точки зору, з авторами, що стверджують: «Тільки системи, далекі від рівноваги, системи в стані нестійкості здатні спонтанно організовувати себе і розвиватися» [12, с. 13]. В людському житті, звичайно, це також діє. Але стан рівноваги, стійкості структур тут має значно більше значення (хоча, розвиток теж, особливо, мікрогенез). Тому існування, рух системи «внутрішній світ» визначається взаємодією не двох, а трьох сил, одна 3 них ніяк не могла враховуватись створювачами синергетики - це свідоме духовне Я (звичайно на тих, більш пізніх етапах онтогенезу, коли воно $\epsilon$ саме в такому стані).

Повторимо, що ми не збираємось тут аналізувати синергетичні погляди в цілому i інтерпретувати їх в галузь психології, хоча підкреслимо, що це - необхідність. Психології давно час перестати кричати про свою унікальність і починати орієнтуватися на найбільш розвинені науки, вже хоча б тому, що вони створені і розвиваються... психікою ж!

Ми вже говорили і наполягаємо: якщо включати аспект генезис внутрішнього світу (а не включати його в наукове дослідження було б неприпустимо безграмотно). Ситуація уявляється дещо іншою. В тому-то й справа, що в психології чомусь так склалося, що більшість явищ (особливо, чомусь, глобальноструктурного порядку) пояснюються без врахування їх генезису. А в такому вигляді явища, як помітив ще Л. С. Виготський [3], виявляються «застиглими» і закритими для дослідника (просто тому, що згорнутість і закритість - властивість структур вищої психіки). Отримані при цьому емпіричні дані, взагалі-то мало відповідають дійсності, оскільки ми все рівно «додаємо» процес їх розвитку, але додаємо не науковим способом, а з власного досвіду, філософсько-релігійних побудов та історичних паралелей. Що ж, слід констатувати, що ми так і не навчилися науково досліджувати розвиток... Тому і виходить, що внутрішній світ «за об’ємом» більший за зовнішній... (і це відчувається цілком об'єктивно буквально кожною людиною, а не лише тільки філософом Бердяєвим). Наше уявлення - теж гіпотеза, адже психологія не має можливості вивчити емпірично ті етапи онтогенезу, про які йшло- 
ся. Вона має, на наш погляд, деякі позитиви, які прокоментуємо. Головне, на наш погляд, полягає у тому, що ідея розвитку, становлення дозволяє відслідкувати динаміку і зміст утворення внутрішнього світу людини i, тим самим, дати набагато більш адекватну картину його будови і функціонування. Які факти дали нам можливість запропонувати таку гіпотезу? Вони - дуже різні і взяті з різних галузей людського життя і наукової думки зокрема. Безумовно, вся ця історія двох люблячих людей відбувається у світі зовнішньому, у життєвому зовнішньому світі кожного з них. I внутрішні життєві світи цих людей не відокремлені один від одного і від світу зовнішнього, а сполучені між собою і утворюють єдність. На якомусь етапі їх життя їхній любові виявляється мало їх двох - переживання любові перестає бути завершеним і вимагає такого завершення. Цим завершенням (цим «піковим переживанням»міг би сказати А. Маслоу) є втілення (цілісне втілення!) їх один в одного з появою результату цього втілення - спільного твору, нової людської істоти, людини. Цей процес може йти по-різному. Може - так, як говорив В. В. Давидов - спочатку виникає ідея, думка, бажання і це вже є виникненням внутрішнього світу дитини (від Платона - ідеальне цілком може існувати об'єктивно). А може бути й поіншому: любовна пристрасть (якщо це - любов!) у кожного з люблячих має періодичну тенденцію до різкого підйому. Мобілізація всих сил організму $з$ тим, щоб на найвищій точці отримати те переживання, що має створююче-породжуючий характер. I таке «створення» людини є вище, на що здатні люди (але вони можуть про це не говорити заздалегідь - вони просто дуже і по-справжньому люблять). Саме в цей момент всі сили двох фізичні, духовні, моральні, психологічні небувалим чином активізуються і об’єднуються, виплескуючись у твір любові - початок дитини.

Ми проінтерпретуємо ще лише один факт, пов'язаний з існуванням і розвитком систем високої складності і нелінійності - факт, що має, нам здається, не лише теоретичне, а й серйозне прикладне значення. Мова йде про управління розвитком даних систем.

Відомо, що в період розвитку (коли значну роль має хаос і коли старі структури руйнуються і змінюються новими), система стає дуже чутливою, але для слабких впливів. Виявляється, головне - не сила, а правильна топологічна конфігурація, архітектура впливу на складну систему в цей час. Маленькі (слабенькі), але вірно організовані - резонансні - впливи на складні системи виявляються дуже ефективними. В той же час, внутрішній світ людини настільки складна система, в ній так важко знайти адресність «правильного впливу», що ми приєднуємося до авторів, які вважають: «стає очевидним, що складно організованим системам не можна нав'язувати шляхи їх розвитку. Швидше, необхідно зрозуміти, як сприяти їх власним тенденціям розви- 
тку, як виводити системи на ці шляхи... Проблема керованого розвитку набуває, таким чином, форму проблеми самокерованого розвитку» [7, с. 4].

В цій фразі, на наш погляд - ціла програма для практичної психології і педагогіки.

\section{Висновки.}

1. Внутрішній світ має такі обов'язкові параметри, як великий рівень складності, висока нелінійність, упорядкованість і структурованість (а отже - ієрархізованість), сингулярність, здатність до продуктивності, розвитку і саморозвитку.

2. В цілому, зазначимо, орієнтація психології на найновіші, найпрогресивніші досягнення найбільш розвинених наук $-\epsilon$ i виходом із кризи і кроком випередження цих наук, адже, повторимо, їх роблять люди.

\section{Перелік використаних джерел:}

1. Бейтсон Г. Экология разума. Избранные статьи по антропологии, психотерапии и эпистемологии / Г. Бейтсон. - М.: Смысл, 2000. - 476 с.

2. Войцехович В. Э. Синергетическая концепция фракталов (социальные и философские основания) / В.Э. Войцехович // Синергетическая парадигма. Т. 3. Человек и общество в условиях нестабильности. - М.: Прогресс-Традиция, 2003. - С. 141-156.

3. Выготский Л. С. О психологических системах / Л.С. Выготский // Выготский Л.С. Собрание сочинений. В 6ти т. - Т. 1. - М.: Педагогика, 1982. - С. 109-131.

4. Выготский Л. С. Проблема возраста / Л.С. Выготский // Собр. соч.: В 6-ти т. - М.: Педагогика, 1983. - Т. 4. -332 c.

5. Данилов Д. Г. Герман Хакен о синергетике / Д.Г. Да- нилов // Синергетическая парадигма. Нелинейное мышление в науке и исскусстве. - М.: Прогресс-Традиция, 2002. - C. 22-27.

6. Донченко E. A. Фрактальная психология: Доглубинные основания индивидуальной и социетальной жизни / Е.А.Донченко. - К.: Знання, 2005. -323 с.

7. Князева E. Н. Синергетика как новое мировидение: диалог с И. Пригожиным / Е.Н. Князева, С.Н. Курдюмов // Вопросы философии, 1992, №12. - С. 3-20.

8. Леонтьев А. Н. Избранные психологические произведения: В 2-х т / А.Н. Леонтьев. - М.: Педагогика, 1983.

9. Лопатин Л. М. Метод самонаблюдения / Л.М. Лопатин // Российская психология. Антология / Сост. А.Н.Ждан. - М.: Академический проект; М.: Альма Матер, 2009. - С. 205-244.

10. Маслоу A. Мотивация и личность / А. Маслоу. СПб.: Питер, 2007. - 352 с.

11. Платонов $K$. K. Структура и развитие личности / К.К.Платонов; Под ред. А.Д.Глоточкина; Академия Наук СССР, Институт психологии. - М.: Наука, 1986. $255 \mathrm{c}$.

12. Пригожин И. Порядок из хаоса: Новый диалог человека с природой / И. Пригожин, И. Стенгерс. - М.: Прогресс, 1986. - 430 с.

13. Рубинштейн С. Л. Бытие и сознание. Человек и мир / С.Л. Рубинштейн. - СПб.: Питер, 2003. - 512 с.

14. Сергиенко E. A. Раннее когнитивное развитие. Новый вигляд. - М.: Изд-во „Институт психологии РАН", 2006. - 463 с.

15. Скороходова О. И. Как я воспринимаю, представляю и понимаю окружающий мир / О.И. Скороходова. Под ред. А.И. Мещерякова. - М.: Педагогика, 1990. $416 \mathrm{c}$.

16. Словарь Л. С. Выготского / под ред. А.А. Леонтьева. - М.: Смысл, 2010. - 118 с.

17. Степин В. С. Теоретическое знание / В.С. Степин. М.: Прогресс-Традиция, 2000. - 744 с.

18. Ухтомский А. А. Сочинения / А.А. Ухтомский. - Л.: Изд-во Ленингр. ун-та, 1945. - Т.5.

19. Хиллман Дж. Внутренний поиск / Дж. Хиллман. - 
М.: Когито-Центр, 2004. - 335 с.

20. Холодная M. А. Психология интеллекта: Парадоксы исследования / М.А.Холодная. - 2-е доп. и перераб. изд. - СПб.; М.; Х., Минск: Питер, 2002. -272 с.

21. Шnет Г. Г. Философско-психологические труды /

Г.Г. Шпет. - М.: Наука, 2005. - 428 с.

22. Шnет Г. Г. Эстетические фрагменты / Г.Г. Шпет. М.: Директ-Медиа, 2008. - 257 с.

23. Юнг К.-Г. Символическая жизнь / К.Г. Юнг. - М.: «Когито-Центр», 2003. - 326 с.

24. Юнг К.-Г. Становление личности / К.Г. Юнг // Психология личности / Под ред. В.Усманова. - СПб.: Питер, 2005. - C. 65-80.

\section{References (Transliteration):}

1. Bejtson G. Jekologija razuma. Izbrannye stat'i po antropologii, psihoterapii i jepistemologii / G. Bejtson. M.: Smysl, 2000. - 476 s.

2. Vojcehovich $V$. Je. Sinergeticheskaja koncepcija fraktalov (social'nye i filosofskie osnovanija) / V.Je. Vojcehovich // Sinergeticheskaja paradigma. T. 3. Chelovek i obshhestvo v uslovijah nestabil'nosti. - M.: Progress-Tradicija, 2003. - S. 141-156.

3. Vygotskij L. S. O psihologicheskih sistemah / L.S. Vygotskij // Vygotskij L.S. Sobranie sochinenij. V 6-ti t. T. 1. - M.: Pedagogika, 1982. - S. 109-131.

4. Vygotskij L. S. Problema vozrasta / L.S. Vygotskij // Sobr. soch.: V 6-ti t. - M.: Pedagogika, 1983. - T. 4. - 332 s.

5. Danilov D. G. German Haken o sinergetike / D.G. Danilov // Sinergeticheskaja paradigma. Nelinejnoe myshlenie v nauke i isskusstve. - M.: Progress-Tradicija, 2002. - S. 22-27.

6. Donchenko E. A. Fraktal'naja psihologija: Doglubinnye osnovanija individual'noj i societal'noj zhizni / E.A.Donchenko. - K.: Znannja, 2005. -323 s.

7. Knjazeva E. N. Sinergetika kak novoe mirovidenie: dialog s I. Prigozhinym / E.N. Knjazeva, S.N. Kurdjumov // Voprosy filosofii, 1992, №12. - S. 3-20.
8. Leont'ev $A$. $N$. Izbrannye psihologicheskie proizvedenija: V 2-h t / A.N. Leont'ev. - M.: Pedagogika, 1983.

9. Lopatin L. M. Metod samonabljudenija / L.M. Lopatin // Rossijskaja psihologija. Antologija / Sost. A.N.Zhdan. M.: Akademicheskij proekt; M.: Al'ma Mater, 2009. - S. 205-244.

10. Maslou A. Motivacija i lichnost' / A. Maslou. - SPb.: Piter, 2007. -352 s.

11. Platonov $K$. K. Struktura i razvitie lichnosti / K.K.Platonov; Pod red. A.D.Glotochkina; Akademija Nauk SSSR, Institut psihologii. - M.: Nauka, 1986. - 255 s.

12. Prigozhin I. Porjadok iz haosa: Novyj dialog cheloveka s prirodoj / I. Prigozhin, I. Stengers. - M.: Progress, 1986. $-430 \mathrm{~s}$.

13. Rubinshtejn S. L. Bytie i soznanie. Chelovek i mir / S.L. Rubinshtejn. - SPb.: Piter, 2003. - 512 s.

14. Sergienko E. A. Rannee kognitivnoe razvitie. Novyj vigljad. - M.: Izd-vo „Institut psihologii RAN”, 2006. $463 \mathrm{~s}$.

15. Skorohodova O. I. Kak ja vosprinimaju, predstavljaju i ponimaju okruzhajushhij mir / O.I. Skorohodova. Pod red.

A.I. Meshherjakova. - M.: Pedagogika, 1990. - 416 s.

16. Slovar L. S. Vygotskogo / pod red. A.A. Leont'eva. M.: Smysl, 2010. - 118 s.

17. Stepin V. S. Teoreticheskoe znanie / V.S. Stepin. - M.: Progress-Tradicija, 2000. - 744 s.

18. Uhtomskij A. A. Sochinenija / A.A. Uhtomskij. - L.: Izd -vo Leningr. un-ta, 1945. - T.5.

19. Hillman Dzh. Vnutrennij poisk / Dzh. Hillman. - M.: Kogito-Centr, 2004. - 335 s.

20. Holodnaja M. A. Psihologija intellekta: Paradoksy issledovanija / M.A.Holodnaja. - 2-e dop. i pererab. izd. SPb.; M.; H., Minsk: Piter, 2002. -272 s.

21. Shpet G. G. Filosofsko-psihologicheskie trudy / G.G. Shpet. - M.: Nauka, 2005. - 428 s.

22. Shpet G. G. Jesteticheskie fragmenty / G.G. Shpet. M.: Direkt-Media, 2008. - 257 s.

23. Jung K.-G. Simvolicheskaja zhizn' / K.G. Jung. - M.: «Kogito-Centr», 2003. - 326 s. 
24. Jung K.-G. Stanovlenie lichnosti / K.G. Jung // Psihologija lichnosti / Pod red. V.Usmanova. - SPb.: Piter, 2005. - S. 65-80.

\section{Papucha Mykola}

Ph.D. in Psychology, professor, Nizhyn Gogol State University, Nizhyn (Ukraine)

INNER WORLD AS THE SYSTEM WITH THE HIGH LEVEL OF NONLINEARITY

\section{ABSTRACT}

The article analyzes substantial difference of «inner world» system from other systems of high complexity and non-linearity which constitutes in its dirigibility (applicable not only to static inner structure, but to the very dynamics of inner world) by the factor, externally related to the system itself - a person who obtains this system. It is proved that personality, and only it, comes forward as the subject of its own inner world. It is mentioned that inner world has such necessary parameters, as high complexity level, increased non-linearity, efficiency and structuredness (and hierarchy subsequently), singularity, abilities of productivity, development and self-development. It is underlined that realization of administrative and regulatory (in fact, subject) functions in relation to inner world takes place through its structurization and re-structurization, mainly through the process of fully external activity. The idea is investigated that development of the system, its self-organization and creation of structures, inevitably requires the state of system unfirmness. It is achieved by presence and simultaneous intrasystem activity of two forces, identical by power rates but directed oppositely. It is underlined that one of those forces assists creation of structures, but at the same time increases heterogeneities in the environment (taking into account heterogeneous nature of the structure). Conclusion is drawn, that this process assists oppositions emergence and thus generates the second force intended for structures dispersion and erosion of all heterogeneities of the system. Action of this force disables structural fromation. But the process of development does not terminate completely. This force generates chaos, and on microlevel it comes forward not as destruction factor, but as force, which leads to self-structurization by appearance of nonlinear environment (attractor). It is notes that systems, similar to human psyche, include so-called «strange attractor» - future state of the system. It is summarized, that this theory does not abolish determinism: existence and development of inner world of a person still determine his/her future.

Key words: inner world, personality, system, development.

\section{Папуча Николай Васильевич}

Доктор психологических наук, профессор, заведующий кафедрой общей и практической психологи, Нежинский государственный университет имени Н.В. Гоголя, г. Нежин (Украина)

\section{ВНУТРЕННИЙ МИР КАК СИСТЕМА С ВЫСОКОЙ СТЕПЕНЬЮ НЕЛИНЕЙНОСТИ}

Аннотация. В статье анализируется существенное отличие системы «внутренний мир» от других систем высокой сложности и 
нелинейности, которая заключается в еe управляемости (не только собой, своей динамикой - самоорганизация), но и внешним по отношению к системе фактором - человеком, который эту систему имеет. Доказывается, что личность, и только она, выступает в качестве субъекта собственного внутреннего мира. Отмечается, что внутренний мир имеет такие обязательные параметры, как большой уровень сложности, высокая нелинейность, упорядоченность и структурированность (а следовательно - иерархичность), сингулярность, способность к производительности, развитию и саморазвитию. Подчеркивается, что осуществление управленческо-регулятивных (собственно, субъектных) функций по отношению к внутреннему миру происходит через его структуризацию и переструктурирование, в том числе и главным образом в процессе полностью внешней деятельности.

Исследуется идея о том, что развитие системы, то есть ее самоорганизация и создание структур неизбежно требует состояния нестойкости системы. Это достигается наличием и одновременной деятельностью в системе двух сил, одинаковых по энергетическому показателю и направленных противоположно. Подчеркивается, что одна из них способствует созданию структур, но, в то же время наращивает неоднородности в среде (вспомним гетерогенную природу структуры). Делается вывод, что этот процесс способствует появлению противоположностей и будто порождает вто- рую силу, направленную на рассеивание структур и размывание всех неоднородностей системы. В режиме действия этой силы структуры не могут возникать. Но процесс развития не прекращается. Эта сила порождает хаос, и он на микроуровне выступает не в качестве фактора разрушения, а силой, выводящей на самоструктурирование появлением нелинейной среды (аттрактор). Отмечается, что в системах, близких по природе к человеческой психике, действует так называемый «странный аттрактор» - будущее состояние системы. Подытоживается, что данная теория не «отменяет» детерминизм - существование и развитие внутреннего мира человека детерминирует его будущее.

Ключевые слова: внутренний мир, личность, система, развитие.

Дата отримання статті: 20.03.2018 Дата рекомендації до друку: 28.03.2018 